\title{
KONFLIK INTERNAL TOKOH UTAMA DALAM NOVEL LINTANG KARYA NANA RINA
}

\author{
Dodi Probowibowo \\ Kantor Bahasa Provinsi Gorontalo \\ Jalan dr. Zainal Umar Sidiki, Tunggulo, Kecamatan Tilongkabila, Kabupaten Bone Bolango, \\ Pos-el : dodiprobowibowo507@gmail.com
}

\begin{abstract}
Abstrak
Karya sastra mengungkap emosi yang timbul dari konflik antartokoh di dalamnya.Penelitian ini bertujuan mendeskripsikan wujud konflik internal yang dialami tokoh utama, dalam novel Lintang. Sumber data penelitian ini adalah novel Lintang karya Nana Rina, cetakan pertama tahun 2012 dan diterbitkan oleh Penerbit Mara Pustaka Yogyakarta. Penelitian difokuskan pada permasalahan yang berkaitan dengan konflik internal yang dikaji secara psikologi sastra. Data diperoleh dengan teknik membaca dan mencatat. Data dianalisis dengan teknik analisis deskriptif kualitatif. Keabsahan data diperoleh melalui validitas semantis dan reliabilitas interrater dan intrarater. Dari hasil penelitian, diperoleh wujud konflik internal tokoh utama, berwujud: kekecewaan akibat tidak tercapainya sebuah harapan, keraguan terhadap keyakinan agama dengan hadirnya informasi baru, kebingungan dalam menentukan pilihan, perasaan bersalah pada orang tua, perasaan bersalah pada Tuhan, perasaan bersalah pada suami, perasaan menyesal pada kesalahan yang sudah diperbuat, kebingungan dalam menghadapi tragedi kehidupan, kekecewaan akibat perasaan yang sudah dilukai, keraguan atas kemampuan diri dalam menyelesaikan masalah. Kebingungan dalam menghadapi tragedi kehidupan adalah wujud konflik internal yang paling dominan yang dialami oleh tokoh utama dalam novel Lintang.
\end{abstract}

Kata kunci: Konflik internal, psikologi, tokoh, novel

\section{The Internal Conflict of Main Character in Nana Rina' Novel : Lintang}

\begin{abstract}
Literary works reveal the emotions that arise from conflicts between the characters in them. This study aims to describe the form of internal conflict experienced by the main character in the novel Lintang. The data source of this research is the novel Lintang by Nana Rina, the first edition 2012 and published by Mara Pustaka Yogyakarta Publisher. The research is focused on problems related to internal conflicts studied in literarypsychology. Data obtained by reading and taking notes. Data were analyzed using qualitative descriptive analysis techniques. The validity of the data was obtained through semantic validity and interrater and interrater reliability. The result showed, it is obtained the form of the internal conflict of the main character, in the form of disappointment due to not achieving hope, doubt about religious beliefs in the presence of new information, confusion in making choices, feelings of guilt in parents, feelings of guilt towards God, feelings of guilt towards husbands, feelings of regret on mistakes that have been made, confusion in dealing with the tragedy of life, disappointment due to feelings that have been hurt, doubts about one's ability to solve problems. The most dominant conflict in Lintang is how the main character faces her confusion towards the tragedy in her life.
\end{abstract}

Keywords: internal conflict, psychology, characters, novel

\section{PENDAHULUAN}

Karya sastra mengungkap emosi yang timbul dari konflik antartokoh di dalamnya. Emosi itulah yang melibatkan pembaca, yang memungkinkan pembaca mampu merasakan konflik tokoh-tokohnya. Konflik antar tokoh itu timbul dari masalah-masalah yang dihadapi, yang digambarkan pengarang, disarikan dari kenyataan, pengalaman, imajinasi dan nilai-nilai kemanusiaan.
Karya sastra yang ditulis oleh penulis pada dasarnya menampilkan kejadian atau peristiwa. Kejadian atau peristiwa yang terdapat dalam karya sastra dihidupkan oleh tokoh-tokoh yang memegang peran penting dalam cerita. Melalui tokoh inilah seorang pengarang menciptakan peristiwa - peristiwa yang melukiskan kehidupan manusia yang berbeda karena setiap manusia memiliki karakter yang berbeda dengan manusia lainya. Perbedaan itulah yang 
menyebabkan adanya kejadian atau peristiwa yang terjadi dalam karya sastra. Kejadian atau peristiwa tersebut berhubungan dengan konflik, baik konflik dengan orang lain, konflik dengan lingkungan, konflik dengan diri sendiri, maupun konflik dengan Tuhan.

Setiap karya sastra adalah otobiografi pengarangnya pada tahap dan sitiuasi tertentu. Karya sastra adalaah kreasi individu dan juga bersifat individu. Ia merupakan hasil seni kreatif dan imajinatif dengan menggunakan bahasa sebagai mediumnya, sebagai bentuk pengungkapan ulang dari realitas kehidupan di sekitar tempat karya sastra itu dilahirkan, kehidupna manusia dengan segala sikap dan persoalannya.

Menurut Nurgiyantoro (2012:3) fiksi menceritakan berbagai masalah kehidupan manusia dalam interaksinya dengan lingkungan dan sesama, interaksinya dengan diri sendiri, serta interaksinya dengan Tuhan. Manusia diciptakan sebagai makhluk sosial atau homo sapiens yaitu makhluk yang tidak dapat hidup sendiri, melainkan hidup berkelompok. Dalam hidup kelompok itu, mereka diharapkan untuk saling menghargai dan menjaga hubungan dengan sesamanya. Namun pada umumnya manusia dalam kehidupan sehari-hari sering mengalami konflik. Begitu juga yang tercipta dalam manusia rekaan pada suatu karya sastra, setiap tokoh mengalami konflik dalam perjalanan hidupnya.

Pembahasan tentang unsur konflik tokoh dalam sebuah novel semakin diminati oleh pembaca ketika dalam novel tersebut terdapat konflik-konflik yang menarik, menyentuh dan atau menegangkan, terkadang pula karena konflik yang terjadi serupa dengan yang dialami pembaca.
Kedekatan emosional yang timbul dari pembacaan terhadap konflik itu membuat novel menjadi lebih berkesan bagi pembacanya: konflik serupa dialami tokohnya, misalnya kehilangan orang yang dicintai, perselingkuhan, pengkhianatan oleh sahabat sendiri, atau perdebatanperdebatan tentang segala macam prinsip hidup. Akhir-akhir ini muncul sastra yang menyoal berbagai pilihan hidup, pendapat tentang kebebasan beragama, ataupun prefrensi seksual. Tema-tema konflik semacam itu meramaikan novel-novel sastra Indonesia.

Konflik membuat sebuah novel semakin hidup dan seru. Konflik yang terjadi dalam sebuah cerita baik itu antara satu tokoh dengan tokoh yang lain atau dengan dirinya sendiri dapat berhasil apabila memunculkan sebuah luapan emosi bagi pembacanya, sehingga pembaca seolah-olah berada di posisi tokoh tersebut. Dengan demikian, dapat dikatakan bahwa cerita itu akan menjadi hidup kalau ada konflik yang terjadi pada tokoh. Bentuk konflik yang erat kaitanya dengan objek penelitian adalah konflik yang terjadi dengan diri sendiri. Objek penelitian ini adalah novel karya Nana Rina berjudul Lintang yang terbit pada tahun 2012.

Penelitian yang mengkaji konflik dalam karya sastra telah banyak dilakukan, akan tetapi hal itu bukan berarti bahwa penelitian mengenai konflik tersebut tidak perlu lagi dilakukan. Mengapa? Manusia adalah makhluk yang kompleks, misterius, dan tak henti dikaji. Novel-novel yang menggambarkan konflik apalagi dari segi psikologis tokohnya menjadi penting untuk melengkapi wahana penelitian dan kajian psikologi sastra.

Salah satu penelitian yang pernah membahas konflik tokoh adalah Penelitian 
Abie berjudul Analysis of Conflict in the Novel Children of Their Parents (Abie, 2020). Konflik yang dominan dalam novel itu adalah konflik eksternal, berupa konflik manusia versus manusia. Ada pula konflik tokoh dengan dirinya sendiri (konflik internal) terjadi pada saat tokoh utama berkelahi dengan dirinya sendiri karena kematian ayahnya yang tak terduga. Di sisi lain, konflik eksternal dilihat sangat tinggi dalam tiga hal: manusia versus manusia, manusia versus masyarakat, dan manusia versus Tuhan. Selain itu, tokoh utama (Brook) mengalami konflik dengan masyarakat dan Tuhan. Dalam penelitian itu, penulis juga meyakini bahwa ada hubungan yang erat antara konflik dan plot. Jalan cerita tidak dapat memiliki jiwa jika tidak ada konflik. Oleh karena itu, konflik dalam novel memainkan peran kunci dalam aransemen peristiwa dalam cerita untuk bergerak maju (2020).

Selain penelitian Abie tersebut, ada penelitian Wahyuni Wumu Tahun 2017, berjudul Tokoh Adeline Yeh Mah dalam Novel Falling Leaves: Pendekatan Psikologi Sastra (Wumu, 2017). Tulisan tersebut mengkaji kepribadian tokoh Adeline, konflik psikologis yang dialaminya dan sikapnya dalam menghadapi berbagai konflik dalam kehidupannya dalam memoar Falling Leaves berdasarkan teori kepribadian psikoanalisis Sigmund Freud. Tulisan tersebut menggunakan pendekatan psikologi sastra. Dari hasil analisis ditemukan bahwa bahwa tokoh Adeline merupakan sosok selalu berusaha menyenangkan hati orangtuanya, sosok yang cerdas, berprinsip, memiliki harga diri dan tangguh meskipun melalui cobaan yang keras seperti keharusan hidup sederhana meskipun dia kaya raya, dan memprihatinkan dengan pengalaman buruk dalam kehidupannya berkat kehadiran ibu dan saudara tirinya, terlepas dia berasal dari keluarga kaya (2017, hlm 159).

Penelitian lain mengenai tokoh utama juga dilakukan oleh Ratih Rahayu dnegan judul tulisan: Tinjauan Psikologi Sastra terhadap Tokoh Utama Novel Rembulan Tenggelam di Wajahmu Karya Tereliye (Rahayu, 2017). Tulisan tersebut mendeskripsikan tokoh utama novel Rembulan Tenggelam di Wajahmu (RTDW) karya Tere Liye ditinjau dari psikologi sastra khususnya teori psikoanalisis Sigmund Freud. Tokoh utama dalam novel ini adalah Ray atau Rehan Rejana. Kisah dalam RTDW didominasi oleh pergolakan batin tokoh utamanya. Tokoh utama novel ini dikisahkan diberi kesempatan untuk melakukan perjalanan mengenai masa lalunya demi menjawab lima pertanyaan dalam hidupnya itu. Pada bagian awal, id Ray muncul secara dominan dan terlihat tidak mampu diimbangi oleh ego dan superego-nya. Ada beberapa saat di mana id Ray muncul dan menjadi dominan. Ada saat di mana Ray juga tidak dapat menerima kenyataan dan merasa Tuhan tidak bersikap adil padanya serta suka merenggut kebahagiaan dari orang-orang baik. Di balik semua bentuk protesnya pada Tuhan, superego tokoh utama RTDW ini masih muncul terutama saat melihat rembulan. Dikisahkan bahwa Ray diberi kesempatan lima hari sebelum kematiannya untuk mengendalikan dominasi id-nya sehingga akhirnya id, ego, dan superegonya berjalan beriringan.

Penelitian ini berbeda dari ketiga penelitian yang dipaparkan pada bagian pendahuluan ini. Pertama, penelitian ini menitikberatkan pada konflik internal yang dialami tokoh. Kedua, novel ini diangkat dari kisah nyata dan mampu memaparkan apa yang terjadi dalam kehidupan sehari- 
hari dan mampu mengapresiasikan pengarang dari konflik-konflik yang terjadi. Ketiga, novel ini, sepanjang pengetahuan penulis, masih jarang dibahas dan dikaji, sehingga diharapkan penelitian ini dapat membuka pemahaman tentang ragam karya sastra khususnya novel dengan cara memahami konflik internal yang dialami oleh tokoh utama khususnya dengan kajian psikologi sastra.

\section{TEORI}

Pendekatan psikologi dalam studi sastra adalah suatu pendekatan yang berlandaskan pada teori-teori psikologi.

Endaswara berpendapat bahwa psikologi sastra adalah kajian sastra yang memandang karya sastra sebagai aktivitas kejiwaan (2003). Pengarang akan menggunakan cipta, rasa dan karsa dalam berkarya. Begitu pula pembaca, dalam menanggapi karya juga tidak lepas dari kejiwaan masing-masing. Bahkan sebagaimana sosiologi refleksi, psikologi sastra pun mengenal karya sastra sebagai pantulan kejiwaan. Pengarang akan menangkap gejala kejiwaan kemudian diolah ke dalam teks dan dilengkapi dengan kejiwaannya (2007, Hlm.96).

Sementara itu, menurut Semi (1989:43-46), pendekatan psikologi adalah pendekatan penelaahan sastra yang menekankan pada segi-segi psikologi yang terdapat dalam suatu karya sastra. Hal ini terjadi karena timbulnya kesadaran bagi seorang pengarang yang dengan sendirinya juga bagi para kritikus sastra, bahwa perkembangan dan kemajuan masyarakat di zaman modern ini tidaklah semata-mata dapat diukur dari segi material, tetapi juga dari segi rohaniah atau kejiwaan. Senada dengan pengertian diatas, Tarigan (1986:213) menyatakan bahwa kritik sastra yang mendalami segi-segi kejiwaan suatu karya sastra. Berdasarkan pengertian di atas mengenai psikologi dapat disimpulkan bahwa psikologi sastra merupakan salah satu pendekatan sastra yang ditekankan pada segi-segi kejiwaan yang mendeskripsikan melalui tokoh-tokoh yang terdapat dalam karya sastra dimana tokohtokoh tersebut hanya ditampilkan.

Psikologi sastra adalah kajian sastra yang memandang karya sebagai aktivitas kejiwaan pengarang akan menggunakan cipta, rasa, dan karya dalam berkarya. Begitu pula pembaca, dalam menanggapi karya juga tak lepas dari kejiwaan masingmasing, sehingga psikologi sastra mengenal karya sastra sebagai pantulan kejiwaan (Endraswara 2003:96), karya sastra yang dipandang sebagai fenomena psikologis akan menampilkan aspek-aspek kejiwaan melalui tokoh-tokoh jika teks berupa drama maupun prosa. Sedangkan jika berupa puisi, tentu akan tampil melalui larik-larik dan pilihan kata yang khas. Pada dasarnya, psikologi sastra akan ditopang oleh tiga pendekatan sekaligus. Pertama, pendekatan tekstual, yang mengkaji aspek psikologis tokoh dalam karya sastra. Kedua, pendekatan reseptif-pragmatik, yang mengkaji pembaca sebagai penikmat karya sastra yang terbentuk dari pengaruh karya yang dibacanya, serta proses resepsi pembaca dalam menikmati karya sastra. Ketiga, pendekatan ekspresif yang mengkaji aspek psikologis sang penulis ketika melakukan proses kreatif yang terproyeksi lewat karyanya, baik penulis sebagai pribadi maupun wakil masyarakat (2007).

Secara definitif, tujuan psikologi sastra adalah memahami aspek-aspek kejiwaan yang terkandung dalam suatu karya. Meskipun demikian, bukan berarti 
bahwa analisis psikologi sastra sama sekali terlepas dengan kebutuhan masyarakat. Sesuai dengan hakikatnya, karya sastra memberikan pemahaman terhadap masyarakat secara tidak langsung. Ada tiga cara yang dapat dilakukan untuk memahami hubungan antara psikologi dengan sastra, yaitu: a) memahami unsurunsur kejiwaan pengarang sebagai penulis, b) memahami unsur-unsur kejiwaan tokohtokoh fiksional dalam karya sastra, dan c) memahami unsur-unsur kejiwaan pembaca (Ratna, 2011:342-343).

Ilmu psikologi digunakan sebagai salah satu kajian dalam menelaah karya sastra terutama untuk mengkaji tokohtokohnya. Psyche oleh Jung (via Suryabrata, 2008:156-157) diartikan sebagai totalitas segala peristiwa psikis baik yang disadari maupun tidak disadari. Jadi jiwa manusia terdiri dari dua alam yaitu (1) alam sadar (kesadaran), dan (2) alam tak sadar (ketidaksadaran). Kedua alam itu tidak hanya saling mengisi, tetapi berhubungan secara kompensatoris. Adapun fungsi kedua-duanya adalah penyesuaian, yaitu (1) alam sadar: penyesuaian terhadap dunia luar, (2) alam tak sadar: penyesuaian terhadap dunia dalam. Batas antara kedua alam itu tidak tetap, melainkan dapat berubah-ubah, artinya luas daerah kesadaran atau ketidaksadaran itu dapat bertambah atau berkurang.

\section{METODE}

Data utama dalam penelitian kualitatif berupa kata-kata dan tindakan, selebihnya adalah data tambahan seperti dokumen-dokumen lainya (Lofland dalam Moleong, 2013: 157). Sumber data penelitian ini adalah novel Lintang karya Nana Rina yang diterbitkan Mara Pustaka pada tahun 2012 dengan ketebalan 273 halaman. Penelitian ini difokuskan pada konflik internal yang dialami tokoh utama dalam novel Lintang.

Pengumpulan data dilakukan dengan teknik membaca dan mencatat. Kegiatan pembacaan dilakukan berulangulang karena didasarkan pada dokumen yang berupa data verbal. Teknik pembacaan tersebut berupa (1) membaca dengan cermat keseluruhan isi novel yang dipilih sebagai fokus penelitian, (2) menandai bagian-bagian tertentu yang diasumsikan mengandung unsur-unsur konflik, (3) menginterpretasikan unsur novel tersebut, (4) mendeskripsikan semua data yang telah diperoleh dari langkahlangkah tersebut. Setelah membaca cermat, dilakukan kegiatan pencatatan data pada kartu data. Langkah-langkah yang dilakukan dalam teknik mencatat adalah (1) mencatat hasil deskripsi dan (2) mencatat nukilan-nukilan data dalam novel Lintang karya Nana Rina yang berupa unit kalimat dan subkalimat.

\section{HASIL DAN PEMBAHASAN}

Konflik dalam novel Lintang ini dimulai ketika tokoh utama harus menghadapi berbagai macam cobaan dan masalah dalam kehidupanya. Pada akhirnya, nalar tokoh sudah tidak dapat menjangkau setiap tragedi yang dihadapinya. Berbagai perasaan menghinggapi dirinya atas segala apa yang sudah dihadapi dan dialami tokoh.

"Aku hanya bisa memperhatikan mereka dengan dan diam. Pada Saat seperti ini aku benar-benar merasa tidak berarti. Keluargaku Sibuk memikirkan tindakan terbaik untuk bapak. Ibu terus saja 
menyeka bagian bawah telinga bapak dengan kain hangat. Hatiku miris mendengar jeritan bapak tak berkesudahan."

(Lintang, 2012:15)

Dari kutipan di atas menggambarkan konflik internal yang dialami Lintang semasa masih kecil. Lintang merasa tak bisa berbuat apa-apa dengan keadaan keluarganya yang ditimpa cobaan penyakit yang didera bapaknya, pada saat seperti ini Lintang hanya bisa diam dan pasrah setiap kali melihat kondisi bapaknya yang merasa sangat kesakitan. Keadaan seperti ini yang mengakibatkan Lintang merasa kurang diperhatikan, keluarganya terlalu sibuk dan fokus memikirkan langkah terbaik dalam upaya penyembuhan bapaknya. Ibunya dengan sabar terus saja menyeka bagian yang dirasa bapaknya sakit, dalam keadaan seperti itu bapaknya terus saja mengerang menahan kesakitan. Hal tersebut menambah membuat diri Lintang bingung dan miris setiap kali mendengar bapaknya menjerit.

"Begitu sempurna kehancuran hatiku hari itu. Aku hanya pasrah, tak bisa berbuat apa-apa. Aku hanyalah korban dari permasalahan yang dibuat orang tua. Ada kalanya aku merasa sebagai anak yang disayang, tapi ada kalanya aku merasa diperlakukan di luar batas kewajaran. $\mathrm{Aku}$ menjadi satu-satunya pelampiasan perasaan orang tuaku, perasaan senang, juga emosi tak lagi tertahan. Aku benar-benar merasa boneka yang bisa diperlakukan semaunya."

(Lintang, 2012:18--19)

Kutipan tersebut menggambarkan konflik internal yang dialami Lintang berupa kekalutan yang dirasakan hati Lintang di dalam permasalahan keluarganya. Ia merasa di dalam keluarganya hanya sebagai tempat untuk melampiaskan berbagai macam perasaan orang tuanya, baik saat orang tuanya senang maupun disaat orang tuanya terlibat pertengkaran hebat hingga emosi yang tak lagi bisa tertahankan. Keadaan seperti itu membuat Lintang tertekan di dalam rumahnya, tidak bisa berbuat apa-apa dan hanya pasrah setiap kali kedua orang tuanya adu mulut. Terkadang menjadi anak yang sangat disayang, tetapi terkadang menjadi anak yang diperlakukan di luar batas kewajaran yang berwujud kekerasan fisik akibat pelampiasan amarah orang tuanya saat kedua orang tuanya terlibat pertengkaran. Konflik terjadi karena dua pasangan fungsi jiwa "pikiran dan perasaan" tidak dapat berhubungan secara seimbang. Nalar sudah tidak bisa mengatasi kekecewaan yang dirasakannya. Distribusi gerak jiwa mengalami kegagalan dalam penyesuaiannya sehingga sikap jiwa terbentuk akibat konflik berorientasi pada subjektifitas. Hal tersebut disebabkan karena perasaan jauh lebih mendominasi keputusan.

\section{Kekecewaan akibat tidak tercapainya sebuah harapan \\ Konflik internal dialami tokoh utama berupa kekecewaan akibat tidak tercapainya sebuah harapan dapat dilihat melalui kutipan berikut.}

"Tapi mengapa nasibku tak bersinar seperti bintang? Duh Gusti, mengapa sejak kecil aku merasa nasib baik tak pernah menyapaku? Aku hidup di tengah keluarga juragan batik yang sudah bangkrut. Eyang kakungku, 
Raden Wiyoto Nagoro almarhum, pemilik perusahaan batik "Canthing Mas" yang tersohor di Yogyakarta awal tahun 1930-an." (Lintang, 2012:3-4)

Kutipan di atas menggambarkan konflik yang dialami Lintang berupa kekecewaan akibat tidak tercapainya sebuah harapan seperti yang diinginkannya. Lintang sangat berharap kalau sebuah nama Lintang itu ibarat seperti bintang yang selalu bisa bersinar, menjadi penerang bagi keluarganya, juga semua orang yang ada di sekelilingnya dan menjadi orang yang berguna untuk sesama. Namun, apa yang ia rasakan sangat berbeda walaupun namanya Lintang seperti harapannya bintang yang bersinar, tetapi sejak kecil tak pernah merasakan mendapat nasib baik seperti yang dia impikan. Di dalam keluarganya, Lintang adalah seorang cucu dari Raden Wiyoto Nagoro, pemilik perusahaan batik "Canthing Mas" yang sangat tersohor pada eranya. Namun, sekarang keadaan berbeda perusahaan batik yang dulunya sangat terkenal pada tahun 1930-an itu tinggal nama karena mengalami kebangkrutan. Hal tersebut dikarenakan anak sulung eyang Lintang yaitu Toto Prasojo meninggal dunia saat berumur sepuluh tahun. Toto Prasojo meninggal karena tercebur ke dalam kenceng yang sedang dipakai untuk melorot kain batik. Sejak saat itu eyang Lintang mengalami tekanan hebat hingga tak bersemangat mengurus bisnisnya hingga perusahaan batik "Canthing Mas" pada akhirnya bangkrut.

"Berbagai pertanyaan mendesakdesak di pikiran. Kenapa aku sering diejek teman-teman? Kenapa aku tak bisa merasakan kenyamanan tinggal di pendopo tua itu? Kenapa pula aku memiliki bapak berwatak keras, sakit- sakitan, dan ibu yang sering cekcok dengan eyang putri? Kapan diriku bisa terlepas dari belenggu ini? Aku ingin seperti teman-teman, tertawa lepas, bermain sesuka hati, tak selalu berada dalam kekangan."

(Lintang, 2012:15)

Kutipan tersebut menggambarkan Lintang yang merasa kecewa, keadaan yang menyenangkan seperti yang dirasakan teman-teman seusianya tak bisa dia dapatkan. Lintang hanya menginginkan ia bisa bergembira seperti teman temannya, bisa bermain sesuka hati, bercanda semaunya tanpa selalu berada dalam kekangan dan pengawasan ketat kedua orang tuanya. Keadaan dirinya yang berbeda dengan yang lain terkadang menjadi bahan olokan teman-temanya. Ia tak bisa merasakan hidup nyaman dengan tinggal di pendopo tua membuat dirinya kecewa dan sedih. Apalagi ia harus mendapati bapaknya yang berwatak sangat keras, sakit-sakitan ditambah ketidakakuran ibunya yang sering cekcok karena berbeda pendapat dengan neneknya. Semua keadaan ini membuat Lintang merasa tak nyaman berada di tengah keluarganya.

\section{Kekecewaan pada perasaan yang sudah dilukai}

Kekecewaan akibat perasaan yang sudah dilukai ini juga merupakan konflik tambahan dari wujud konflik internal yang dialami tokoh. Konflik ini dimulai ketika Lintang mendapati surat dari Anggit yang isinya tak bisa melanjutkan hubungan dengan Lintang.

$$
\begin{aligned}
& \text { “...tapi surat Anggit itu } \\
& \text { membuatku seperti tersengat } \\
& \text { petir, badanku mendadak kaku } \\
& \text { setelah membaca suratnya. }
\end{aligned}
$$


Persendianku lemas seketika. Aku ingin menjerit, tapi tak mampu bersuara, hanya berhenti di tenggorokan. Tubuhku lemah terkulai, memegangi kertas putih yang telah menentukan nasib hubunganku dengan Anggit." (Lintang, 2012:42)

Kutipan di atas menggambarkan kekecewaan Lintang pada Anggit yang tega melukai perasaanya dengan memutuskan hubungan cintanya dengan Lintang. Saat itu, perasaan campur aduk Lintang membuatnya lemas seketika setelah membaca isi surat yang membuat dirinya sangat kecewa. Pengabdian, kesetiaan dan pengorbanannya selama ini untuk mempertahankan cintanya kepada Anggit ternyata hanya sia-sia. Ia ingin menjerit sekeras mungkin, tetapi tak mampu bersuara dengan kondisi badan yang lemah terkulai dengan surat yang sangat menyakitkan di genggaman.

"Mendengar kata-kata itu, seketika dadaku sesak, jantungku berdetak berlipat kali lebih kencang. Persendianku lemas, seakan tak mampu berdiri. Bibirku bergetar ingin berucap sesuatu, tetapi tertahan. Benarkah suamiku memiliki hubungan khusus dengan istri orang itu. Batinku bagai tersambar petir. Karena tak kuat menahan beban perasaan, kutidurkan Anti di ranjang bayinya." (Lintang, 2012:73)

Kutipan tersebut menggambarkan konflik yang dialami Lintang berwujud kekecewaan pada perasaan yang sudah dilukai setelah mengetahui suaminya ternyata pernah berselingkuh dengan istri temannya sendiri. Tanpa sengaja, Lintang mendengar perbincangan seorang tamu dengan suaminya. Dari perbincangan tamu tersebut dengan Aji suami Lintang, terdengar keributan yang intinya menanyakan sejauh mana hubungan Aji dengan istrinya tersebut. Mendengar perbincangan itu membuat dadanya sesak, sakit dan merasakan sangat kecewa setelah mengetahui hal yang sebelumnya belum pernah diketahui Lintang. Berbagai pertanyaan terus saja mendesak benaknya, apa benar suaminya telah mempunyai hubungan khusus dengan istri tamu tersebut. Situasi tersebut membuatnya tak kuat menahan beban perasaan di hatinya hingga ia menidurkan Anti anaknya yang masih balita.

\section{Kebingungan dalam menentukan pilihan}

Konflik internal yang berwujud kebingungan dalam menentukan pilihan juga merupakan konflik tambahan dari konflik-konflik lainnya. Konflik ini hanya mempunyai frekuensi pemunculan sebanyak lima kali di dalam alur cerita novel Lintang ini.

"Siapa sebenarnya Dia? Apakah Tuhan yang disebut-sebut pak Hanif sama yang disebut ibu? Saat pelajaran Pendidikan Agama Islam Pak Hanif menyebut Tuhan dengan Allah Subhanahu Wata'ala. Dengan huruf "a" pada kata Allah disebut dengan huruf "o". jadi Alloh. Sementara ibu sering menyebut Tuhan dengan sebutan Allah, dengan huruf "a" tetap dibaca "a". Apa bedanya?"

(Lintang, 2012:12)

Dari kutipan tersebut, digambarkan konflik Lintang berwujud kebingungan dalam menentukan pilihan. Konflik 
tersebut dimulai ketika Lintang masih kecil dimana pada saat pelajaran pendidikan Agama islam, gurunya pak Hafid selalu menyebut Tuhan Allah subhanahu wata'ala dengan huruf "a" pada kata Allah di sebut huruf "o". jadi Alloh. berbeda dengan ibunya yang tetap memakai huruf "a"jadi Allah. Dari situ, Lintang bertanya-tanya dalam hatinya tentang Tuhan yang Allah sebenarnya yang memakai huruf "O $\mathrm{O}$ "e atau dengan huruf A"? Lintang berusaha mencari tahu yang paling benar untuk menjawab kebingungan yang dialami Lintang terhadap kedua pilihan tersebut.

"Semakin sering Aji datang ke rumah. Semakin aku bisa memahami ada maksud lain yang bersembunyi di hati Aji. Aku mulai menyadari dia menaruh hati padaku. Sedang aku sendiri belum yakin apakah aku mencintainya, atau hanya sekedar menganggapnya sebagai kakak." (Lintang, 2012:28)

Kutipan tersebut menggambarkan konflik yang dialami Lintang yang kebingungan dalam menentukan pilihanya. Hal tersebut dimulai ketika Aji yang sering datang ke rumah, Lintang menyadari kalau seringnya Aji datang ke rumah bukan hanya sekedar main ke rumah biasa tetapi sebenarnya Aji mempunyai maksud lain datang ke rumahnya. Seringnya Aji datang ke rumah membuat Lintang tahu apa yang sebenarnya dirasakan Aji terhadapanya. Kebingungan dalam menentukan pilihan pun dirasakan Lintang karena Lintang belum terlalu yakin dengan apa yang ia rasakan. Ia hanya sekedar menganggapnya sebagai kakak atau benar-benar telah mencintai sosok Aji. Konflik yang berwujud kebingungan dalam menentukan pilihan ini terjadi di alam kesadaran tokoh. Fungsi jiwa bekerja secara rasional.
Konflik tersebut terjadi karena benturan dua pemikiran yang sama sehingga mempengaruhi tokoh dan timbul keraguan. Hal tersebut memperlihatkan bahwa antara dua pasang jiwa pemikiran dan perasaan tidak dapat melakukan hubungan seimbang sehingga timbul gangguan berupa kebimbangan. Energi jiwa yang terjadi pada saat terjadi konflik bergerak ke arah penyesuaian, tetapi mengalami kegagalan sehingga sikap jiwa yang akhirnya terbentuk berorientasi pada dunia subjektif.

\section{Perasaan bersalah pada Tuhan}

Konflik internal yang berwujud perasaan bersalah pada Tuhan ini juga merupakan konflik tambahan dari konflikkonflik lainnya.

"...aku merasa tiada berarti
dihadapan-Nya. Aku tak pernah
menjalankan sholat, sejak eyang
putri tak lagi mengawasi. Masa
masa hidupku tak pernah
kugunakan untuk memperdalam
agama. Waktu seperempat abad
umurku terasa begitu sia-sia.
Bahkan setelah menikah, nasihat
suami tak pernah lagi kuindahkan.
Padahal Mas Aji orang yang giat
belajar."
(Lintang, 2012:31)

Kutipan di atas menggambarkan konflik yang dialami Lintang berwujud perasaan bersalah pada Tuhan. Tokoh Lintang tak pernah lagi menjalankan peribadatan dan memperdalam agama sejak eyang putrinya meninggal dunia, karena eyang putrinyalah yang selama ini mengajarkan agama dan mengawasi segala kegiatan keagamaan Lintang di rumah. Bahkan setelah menikah dengan Aji yang selalu rajin dan giat memperdalam agama, seolah nasihat suaminya hanya angin lalu saja. Nasihat itu tetap tak mengubahnya 
untuk melakukan salat. Pada akhirnya, Lintang pun tersadar bahwa selama ini apa yang dia kerjakan hanyalah sia-sia umur seperempat abad pun terasa tak berarti, dirinya tersadar telah melupakan Tuhannya dan berkeinginan kuat untuk berubah dengan berusaha memperbaiki diri dalam hidup dengan memperdalam agama.

"Rasa bersalah dan penyesalan terus mengombangambingkan perasaanku. Aku tak sempat menyadari tubuhku didorong berpindah ruangan, di bawa menuju ruang bedah. Aku tak menyadari, sebentar lagi garis pemisah antara hidup dan mati akan berbeda tipis. Aku tak peduli pada semua itu, pikiranku dan perasaanku sedang larut dalam penyesalan dan perasaan berdosa. Ya Allah, maafkan aku yang hanya mengingatMu saat berada dalam kesulitan. Tolonglah aku, ya Allah, selamatkan aku dan anakku," doaku lirih."

(Lintang, 2012:32)

Dalam kutipan tersebut, digambarkan kekalutan hati Lintang yang merasa menyesal dan bersalah telah melupakan Tuhannya. Hanya pada saat dirinya merasa kesulitan saja dirinya mengingat Tuhan. Ia terlalu larut dalam penyesalan dan merasa berdosa, hingga tak sempat menyadari mulai dibawa ke ruangan bedah, seakan hidup dan mati tak ada pembatasnya.Dia hanya bisa memohon ampunan pada Allah dan tak henti-hentinya berdoa agar dirinya dan anaknya bisa selamat.

\section{Perasaan menyesal pada kesalahan yang sudah diperbuat}

Perasaan menyesal pada kesalahan yang sudah diperbuat ini juga merupakan konflik tambahan dari wujud konflik internal yang dialami tokoh. Konflik ini di mulai ketika tokoh Lintang harus menanggung malu dalam acara pernikahannya dengan Aji karena dirinya sudah hamil sebelum menikah.

"Prosesi pernikahan kami berjalan lancar. Namun, dalam hati terselip rasa sesal yang menyakitkan. Andai saja aib itu tidak ada pasti kebahagiaanku akan lebih sempurna. Aku harus menanggung malu karena badanku yang berbalut kain jarik sudah membesar."

(Lintang, 2012:59).

Kutipan di atas menggambarkan kekalutan hati Lintang yang pada saat pernikahan yang seharusnya berbahagia tapi dirinya harus menanggung malu karena perutnya yang sudah membesar. Kehamilannya sebelum menikah merupakan faktor penyebab utama dirinya menyesal atas perbuatannya. Namun, semua itu dapat terobati karena pernikahannya dengan Aji sangat berjalan dengan lancar dan sakral.

"Walaupun perzinaan belum terjadi, mengingat niatan terbesit di hati, membuat hatiku nyeri yang teramat sangat. Sampai sekarang aku masih merasa menjadi perempuan rendah, hina. Aku tak pernah menduga, peristiwa itu akan memunculkan penyesalan yang terdalam, dan dari penyesalan yang berlarut membuat jiwaku hancur"

(Lintang, 2012:189)

Dalam kutipan di atas, digambarkan gejolak batin Lintang yang hampir melakukan perzinaan dengan lelaki lain tanpa sepengetahuan suaminya. Lintang merasa menyesal tak terperi setiap kali 
mengingat kejadian itu. Ia tak bisa membayangkan jika dirinya sampai melakukan perzinaan itu, dirinya merasa sangat begitu rendah dan hina di depan keluarganya bahkan di depan suaminya. Peristiwa yang dialami Lintang membuat dirinya hancur dan sakit jiwanya.

\section{Perasaan bersalah pada orang tua}

Perasaan bersalah pada orang tua juga merupakan konflik tambahan dari wujud konflik internal yang dialami tokoh utama. Konflik ini berawal dari perasaan tokoh Lintang setelah menyadari apa yang telah dilakukannya itu ternyata tidak benar.

"Aku tak kuasa menjawab. Aku berjalan menunduk. Dadaku berdebar-debar tak karuan. Ada sedikit penyesalan, juga rasa takut. Menyesal karena tak seharusnya membuat bapak marah. Apalagi akhir-akhir ini penyakit bapak sering kambuh."

$$
\text { (Lintang, 2012:13) }
$$

Kutipan tersebut menggambarkan konflik internal yang dialami Lintang berwujud perasaan bersalah pada orang tua. Lintang merasa tak seharusnya membuat bapaknya marah karena ulahnya pada malam itu. Lintang keluar rumah malammalam tanpa diketahui bapaknya. Bapaknya sangat marah karena Lintang tidak pernah menggubris nasihat bapaknya dan masih tetap ingin bermain di luar rumah hingga larut malam. Kejadian tersebut membuat Lintang sadar kalau dirinya salah dan tak ingin menambah beban pikiran bapaknya karena kenakalannya, apalagi penyakit bapaknya gampang kambuh. Pembengkakan dalam telinga kiri bapaknya yang seperti bisul tersebut membuatnya sulit tidur karena harus menahan rasa sakit. "Aku cuma diam menunduk, tak berani mengangkat wajah, meratapi ketololanku dan kenaifanku. Aku berusaha sekuat tenaga untuk tidak menangis. Karena tangis hanya membuatku semakin terpuruk. Aku tak ingin kelihatan lemah, aku ingin tegar menghadapi masalah ini. Dengan ketegaran sikapku, aku berharap Aji tak mudah mencampakkanku."

(Lintang, 2012:57)

Dari kutipan di atas Lintang mengalami gejolak batin karena dirinya merasa telah mengecewakan kedua orang tuanya yang selama ini telah membesarkan dan mendidik dengan sebaik mungkin. Kepercayaan kedua orang tuanya telah disalahgunakan Lintang yang sudah melakukan hubungan dengan Aji hingga membuat dirinya hamil. Dalam kondisi seperti itu dirinya merasa menyesal dan takut dengan kedua orang tuanya, dirinya berusaha untuk tetap tegar dengan kondisi yang telah menimpa dirinya. Hanya satu harapan Lintang agar Aji mau bertanggung jawab dan tidak mencampakkannya.

\section{Perasaan bersalah pada suami}

Perasaan bersalah pada suami ini merupakan konflik yang paling sedikit dirasakan oleh tokoh dalam alur cerita. Konflik ini dimulai ketika tokoh Lintang tak sanggup lagi menyembunyikan rahasia terbesarnya pada sang suami yang akhirnya dengan berani mau berkata jujur pada suaminya walaupun semua itu terasa berat untuk mengatakannya.

"Apakah kau benar-benar tak tahu? Maafkan aku yang telah merusak kesucian cinta kita. Separuh hatiku tlah kuberikan kepada orang lain, Mas. Maafkan aku Mas, yang merasa tak cukup atas kasih sayang yang 
kauberikan. Aku butuh lebih banyak dari itu, Mas. Andai kau mau mengerti perasaanku."

Kutipan di atas menggambarkan tokoh Lintang yang berat hati mengakui kesalahan dan sangat menyesal telah mengkhianati suaminya dengan berselingkuh dengan lelaki lain. Walaupun begitu, Lintang melakukan perselingkuhan hanya sebagai bentuk protes terhadap suaminya yang kurang memberi perhatian lebih terhadap dirinya. Selama berumah tangga dengan Aji, suaminya, Lintang merasa kurang mendapatkan kasih sayang dari suaminya seperti yang dia harapkan.

\section{Keraguan terhadap keyakinan agama dengan hadirnya informasi baru}

Konflik internal tokoh yang berwujud keraguan terhadap keyakinan agama dengan hadirnya informasi baru juga merupakan konflik yang paling sedikit dirasakan oleh tokoh dalam alur cerita.

"Tapi apa yang aku dengar malam ini, memiliki makna yang berbeda. Dulu aku tidak peduli, bahkan menikmatinya. Tapi sekarang, lagu pujian itu membuatku bingung. Tentu saja apa yang aku dengar itu ikut menggoyahkan keyakinan yang baru mulai aku rasakan."

\section{(Lintang, 2012:11)}

Kutipan tersebut di atas menggambarkan konflik yang dialami oleh Lintang karena hadirnya informasi baru tentang agama. Tokoh Lintang menjadi ragu akan keyakinan agama yang baru saja dianutnya dan dipelajarinya. Konflik dimulai ketika Lintang pulang dari tempat tinggal eyang putri, langkahnya tertahan di depan pintu rumah, karena mendengar sayup-sayup suara ibu menyanyikan lagu pujian-pujian gereja. Kejadian tersebut bukan pertama kali lintang mendengar ibunya menyanyikan lagu rohani agama Katolik. Lintang merasakan sesuatu yang berbeda yang dulunya tak peduli dan mengacuhkan lagu-lagu itu bahkan tak menikmatinya, tetapi sejak malam itu, Lintang menjadi bingung karena lagu yang membingungkan pikirannya. Apa yang Lintang dengar membuat dirinya menjadi ragu bahkan menggoyahkan keyakinan yang baru saja dia usahakan untuk di pelajarinya.

\section{Keraguan atas kemampuan diri dalam menyelesaikan masalah}

Konflik internal yang berwujud keraguan atas kemampuan diri dalam menyelesaikan masalah. Konflik ini muncul ketika Lintang ragu dalam menyelesaikan permasalahannya yang merasa selalu tak sempat untuk memiliki waktu melakukan salat lima waktu. Konflik keraguan atas kemampuan diri dalam menyelesaikan masalah juga merupakan wujud konflik yang menempati prioritas paling rendah dialami tokoh dalam alur cerita. Frekuensi pemunculan konflik ini hanya terjadi sebanyak satu kali dibandingkan konflik-konflik lainnya yang dialami tokoh.

"Kenapa begitu sulit meluangkan waktu beberapa menit untuk sholat dua rokaat sholat subuh? Padahal setiap harinya aku bangun jam tiga pagi, melakukan pekerjaan rumah bersama Mbak Siyah. Kenapa memotong beberapa menit waktu jam istirahat kantor istirahat begitu sulit? Saat Ashar berkumandang, biasanya bertepatan dengan giliranku menjaga Gilang. Saat 
masuk waktu Magrib seringkali aku belum sempat membersihkan badan yang terkena ompol Gilang. Begitu tiba waktunya Salat isya dan Gilang tidur, Anti selalu mencariku untuk melaporkan pelajaran barunya di Taman kanak-kanak. Belum lagi terkadang aku membawa lemburan dari kantor. Aku terus bertanya-tanya, kenapa begitu kuat penghalang untuk menjalankan sholat? Apakah itu juga dialami orang lain? Kenapa orang-orang begitu menikmati sholatnya, tak menjadikan sholat sebagai beban?"

(Lintang, 2012:102)

Kutipan tersebut menggambarkan konflik yang dialami Lintang saat dirinya menghadapi keraguan atas kemampuan diri dalam menyelesaikan masalahnya. Konflik ini berawal ketika dirinya merasa begitu sibuknya hingga untuk mendapatkan waktu beberapa menit untuk menjalankan salat yang hanya sebentar tak pernah dia dapatkan. Padahal setiap pagi dirinya bisa untuk bangun pagi tapi untuk melakukan salat yang hanya dua rakaat slalu tidak bisa. Untuk salat duhur Lintang tak sempat untuk mendapatkan waktu istirahat dan di waktu ashar selalu bertepatan dengan menjaga Gilang. Setelah memasuki waktu salat Magrib Lintang pun harus membersihkan ompol Gilang dan membersihkan badannya. Ketika tiba waktunya salat Isya, anaknya yang paling besar Anti selalu mencarinya untuk melaporkan pelajaran yang baru saja Anti dapatkan dari taman kanak-kanak. Dari semua itu, Lintang merasa ragu untuk menyelesaikan persoalan waktu yang tak pernah dia dapati untuk menjalankan salat lima waktu. Berbagai pertanyaan bermunculan di pikirannya kenapa dia tak bisa seperti orang lain yang tak menjadikan salat sebagai beban dalam kehidupan mereka bahkan mereka sangat menikmati salatnya. Konflik internal tersebut terjadi di dalam kesadaran tokoh. Keraguan atas kemampuan diri dalam menyelesaikan masalah terjadi di dalam pikiran tokoh yang bekerja secara rasional. Pertentangan tersebut terjadi dalam satu fungsi jiwa, yaitu pikiran yang pada akhirnya akan membentuk ketidakseimbangan dengan pasangan fungsi jiwanya. Dua kekuatan besar tersebut mengganggu aktifitas kerja fungsi jiwa. Hal tersebut yang menunjukkan konflik internal terjadi pada tokoh, kedua kekuatan melakukan gerak energi ke arah penyesuaian, meski pada akhirnya mengalami kegagalan. Kegagalan penyesuaian yang terjadi dalam distribusi gerak jiwa membentuk sikap jiwa yang subjektif.

\section{PENUTUP}

\section{Simpulan}

Berdasarakan hasil penelitian dan pembahasan yang telah dilakukan dapat diambil kesimpulan bahwa kebingungan dalam menghadapi tragedi kehidupan adalah wujud konflik internal yang paling dominan yang dialami oleh tokoh utama dalam novel Lintang.

Konflik yang dialamai tokoh utama sebagai berikut. Kebingungan dalam menghadapi tragedi kehidupan adalah wujud konflik internal yang paling dominan yang dialami oleh tokoh utama dalam novel lintang. Konflik itu berwujud: kekecewaan akibat tidak tercapaianya sebuah harapan (2) keraguan terhadap keyakinan agama dengan hadirnya informasi baru (3) kebingungan dalam menentukan pilihan (4) perasaan bersalah 
pada orang tua (5) perasaan bersalah pada Tuhan (6) perasaan bersalah pada suami (7) perasaan menyesal pada kesalahan yang sudah diperbuat (8) kebingungan dalam menghadapai tragedi kehidupan (9) kekecewaan pada perasaan yang sudah dilukai (10) keraguan atas kemampuan diri dalam menyelesaikan masalah.

Keterbatasan penelitian ini adalah hanya terfokus pada konflik tokoh utama dan belum meneliti secara utuh aspek psikologi bagimana tokoh lain mempengaruhi konflik yang timbul pada tokoh utama, Lintang.

\section{Saran}

1. Untuk penelitian selanjutnya, diharapkan bisa meneliti dari aspek psikologinya secara utuh yaitu aspek psikologi pengarang dan pembaca.

2. Penelitian ini dapat dijadikan bahan untuk mengembangkan teori sastra dan wacana analisis sastra, serta dapat dimanfaatkan bagi mahasiswa pemerhati sastra dan masyarakat umum, agar memperoleh suatu pengetahuan yang lebih mendalam tentang psikologi sastra dan sastra psikologi.

3. Dalam kaitannya dengan bidang sastra, novel ini juga dapat dijadikan acuan bagi peneliti lain untuk dapat meneliti novel ini dengan kajian yang berbeda, misalnya dilihat dari sudut pandang kajian moral yang terdapat dalam novel atau aspek lain.

\section{DAFTAR PUSTAKA}

Endraswara, Suwardi. Metode Penelitian Psikologi Sastra. 2007. Yogyakarta. Azza Grafika.
Nurgiyantoro, Burhan. 2012. Teori Pengkajian Fiksi. Yogyakarta: Gadjah Mada University Press.

Moleong, Lexy J. 2013. Metode penelitian Kualitatif. Bandung: Rosda

Rayayu, Ratih. Tinjauan Psikologi Sastra terhadap Tokoh Utama Novel Rembulan Tenggelam di Wajahmua Karya Tere liye. Telaga Bahasa Volume 5, No. 1 Juni 2017, halaman 127-142. DOI 10.36843/tb.v5i1.125, diakses 7 April 2020.

Ratna, Nyoman Kutha. 2011. Teori, Metode dan Teknik Penelitian Sastra. Yogyakarta: Pustaka Pelajar.

Rina, Nana. 2012. Lintang (Perjalanan Getir Seorang Perempuan). Yogyakarta: Mara Pustaka.

Wumu, Wahyuni, 2017. Tokoh Adeline

Yeh Mah dalam Novel Falling

Leaves Pendekatan Psikologi Sastra, dalam Telaga Bahasa Volume 5, No. 1 Juni 2017, halaman 159-178. DOI 10.36843/tb.v5i1.125, diakses 7 April 2020.

Tsegaye Abie, Tsegaye. 2020. Analysis of Conflict in the Novel Children of

Their Parents in Research on

Humanities and Social Sciences

Vol.10, No.3, 2020. Diakses 6 Juni 2020.

Semi, Atar. 1989.Kritik Sastra. Bandung: Angkasa Raya.

Suryabrata, Sumadi. 2008. Psikologi Kepribadian. Jakarta: Rajawali Press. 
